Розроблено структуру ознакових семантичних просторів. Отримані простори відображають упорядковане представлення варіативності процесу ожиріння. Таке уявлення дозволяе послідовно поглибити деталізацію процесу формоутворення тіла і отримати безперервний перехід від одного типу порушення обмінних процесів до іншого. Це сприятиме більш точній донозологичній діагностиці, а також ї̈ систематиці. Отримані результати можуть послужити розвитку досліджень особливостей протікання ожиріння $i$ розробці інформаційної системи діагностики даної патології

Ключові слова: семантичний простір, біологічний вік, ліпідний обмін, критерії оцінки, ожиріння

Разработана структура признаковых семантических пространств. Полученные пространства отражают упорядоченное представление вариативности процесса ожирения. Такое представление позволяет последовательно углубить детализацию процесса формообразования тела и получить непрерывный переход от одного типа нарушения обменных процессов $к$ Әругому. Это позволяет обеспечить более точную донозологическую диагностику, а также ее систематику. Полученные результаты могут послужить развитию исследований особенностей протекания ожирения и разработке информационной системы диагностики данной патологии

Ключевые слова: семантическое пространство, биологический возраст, липидный обмен, критерии оценки, ожирение

$\square$

\section{STUDYING THE MECHANISMS OF FORMATION AND DEVELOPMENT OF OVERWEIGHT AND OBESITY FOR DIAGNOSTIC INFORMATION SYSTEM OF OBESITY}

O. Vy s o t s k a Doctor of Technical Sciences, Professor* E-mail: olena.vysotska@nure.ua

H. Dobrorodnia

Postgraduate student* E-mail: hanna.dobrorodnia@nure.ua

N. Gordi y e n k o $\mathrm{PhD}$, Associate Professor** E-mail: nagordienko@yandex.ru

V. K I y m e n k o

Doctor of Medical Sciences, Associate Professor Department of Fundamentals of Pediatrics № 2***

E-mail: klymenkoviktoriia@gmail.com

G. Chovpan

$\mathrm{PhD}$, Associate Professor**

E-mail: chovpan_s@ukr.net

M. Georgi yant s

Doctor of Medical Sciences, Professor, Head of Department Department of Anesthesiology and Intensive Care Kharkiv Medical academy of Postgraduate Education Amosova str., 58, Kharkiv, Ukraine, 61176 *Department of biomedical engineering Kharkov National University of Radio Electronics Nauky ave., 14, Kharkiv, Ukraine, 61166

**Department of Medical and Biological Physics and Medical Informatics $* * *$ ***Kharkiv National Medical University Nauky ave., 4, Kharkiv, Ukraine, 61022

\section{Introduction}

World Health Organization (WHO) has recognized obesity as a global epidemic. The number of people suffering from this disease is growing fast. It is estimated, that it may increase up to 300 million by 2025 . Nowadays, no other disease provokes so many discussions as overweight and obesity. For many years, obesity had not been regarded as a disease, though prerequisites for that existed. Now it is recognized, that overweight lowers viability of important systems of an organism and substantially cuts down lifespan [1].
In the last decades, clinical specialists have started to investigate various metabolic disorders and diseases related to obesity [2]. Pathologies of this kind are united by the term "metabolic syndrome". It is characterized by a number of changes in an organism leading to profound metabolic disorders called "syndrome X". Obesity, hypertonia, elevated cholesterol, and sugar level in blood are the factors that essentially increase the number of infarctions, apoplexies, congestive bronchitis, pneumonia and pneumofibrosis [1].

The solution of such a serious problem as obesity is possible by development of specialized information systems. However, the creation of such systems towards the problem 
of obesity requires studying the mechanisms of its formation. The study of this disease and identification of direction of individual violations of physical development to fight against this pathology is an urgent task.

\section{Literature review and problem statement}

According to statistical surveys, about $20 \%$ of middle and old-aged people suffer from metabolic syndrome. The first stage of obesity, which makes $10-20$ years, is characterized by metabolic disorders. The next period (10-20 years) is characterized by occurrence of atherosclerosis. After that heart attack and stroke occur.

Questions relating to development of means of automation of processes of information analysis are important from a diagnostic, and a therapeutic point of view. Improving the process of automation allows early diagnosis and obesity correction to a qualitatively new level.

One of the easiest ways to control your weight is to use a special online calculator. With the help of these calculators ideal weight (index of Brock, Brock-Brugsch, Mohammed, Borngardt; formula of Monnerot-Dumain, Kreffa, Lorentz, Potton, Devine, Robinson, Miller, Humvee, Nagler, Robert Cooper), normal weight (index Brock, Breitman, Noorden, Taton, Gabs, Beckett, Otto), body area (formula Mosteller, DuBois, Haycock, Gehan and George, Boyd, Fujimoto, Takahira, Schlich), percentage of body fat (based on BMI, US Navy method, method Covert Bailey, method YMCA, an additional method of the YMCA), metabolic age (formula Katch-McArdle, a new Harris-Benedict equation), the rate of metabolism (Harris-Benedict equation, new equation of Harris-Benedict, formula of Mifflin-San Zheora, formula of Ketch-McArdle, on body surface area), the ratio waist - hip, body type, and stage of obesity (BMI) are determined [3].

There is universal medical calculator developed on the basis of MS Office Excel for simultaneous calculation of 13 parameters, among which: body mass index (BMI); ideal body weight (Devine method), and body surface area [4].

There are applications for dietary directions, including for the Android platform. On Google Play, you can find a number of organizers for weight control and consumption. As a typical example, the program Diet Assistant can be given [5].

Despite the fact that today there is such a variety of online calculators, their application is limited by definition of overweight, on the basis of which the doctor can judge about the risk of disease development, caused by obesity. In addition, the calculator does not allow you to store large amounts of data, implement quick search, make changes, correct information, and others.

To use medical information as an integral part of patient-specific, its systematization and generalization is necessary, it is possible with the use of information systems.

In medical practice such information systems as "Diagnos.ru" [6], "Online Diagnostics" [7], "EMSIMED" [8] and others are widely spread.

They are intended to provide automated help in the diagnosis of diseases, including obesity.

Disadvantages include the possibility of misinterpretation of symptoms of obesity due to lack of information on the constitutional features of a person, which help to explain the regularity of morphogenesis. As a result, the system can issue a wrong conclusion.
There is a computer technology of error estimation in determining the mass-inertial characteristics of the human body segments based on a quantitative comparison of the real and calculated anthropometric indices of athletes. The authors have shown that the effect of motor actions depends on constitutional gymnast data. In this case the effect, for example, freewheeling turn in an unsupported state depends on the growth that is shown at equal body weight [9].

The program complex of mathematical modeling of the physical exertion system which allows you to determine the type of body with the help of the Solovyov index is known. An important individual characteristic of a trainee is body weight. For the analysis of body weight a multidimensional array of body mass indices, which includes indices of Quetelet, Brock, Gabsa, Breitman, Bernhard Lorentz, and M. E. Debakey was introduced and synchronized with the corresponding formulas, conditions for the use of formulas and production rules cumulative application of which allows you to prepare conclusions about the degree of sufficiency of body weight of a trainee. Estimation of body weight carried out via the system under consideration only allows to prepare or take the most general primary decision - reduce/ maintain/gain weight [10].

Medical information systems known to date do not fully take into account individual violations of human physical development.

Development of medical recommendations and assessment of the human condition about specific diseases, including obesity, are today only promising opportunities for information systems.

For effective diagnosis of obesity, it is necessary to develop an information system, which would consider the mechanisms of its formation, constitutional features of a person, patterns of body shaping given the growth-weight ratio, which requires the development of appropriate mathematical software.

Anthropometric measurements are a simple and accessible method for assessing the state of the human body. Thus, obtained figures reflect not only the body type and physical development, but also, they are important characteristic for predicting the risk of various diseases [11-13].

A variety of anthropometric methods is caliperometry. However, the results of anthropometric surveys may differ significantly when measured by different specialists and using different types of calipers, as well as formulas for determining the body composition. A significant disadvantage of caliperometry is the need for precise determination of the measurement site and capturing a skin only with subcutaneous fat layer, but not other tissues [14].

Anthropometric characteristics are used in their practices by following the authors [15].

The author for the first time considered the type of body as a morphological individual passport and external reflection of metabolic processes in the body. He found that the proportions of the body are a reflection of individual hormonal influences, which determine predisposition to a particular disease. However, the development remained unclaimed, as it is difficult to compare with each other and the proximity of the remoteness of describing the structure of the observed body types [16].

Was found a series of age-relation of linear features body and the weight man and brought forth the predictive curve of their dependencies, allowing to predict upcoming changes and possible disturbances in health. Based on studies predic- 
tive curve for body parts has been proposed, which allows to find a predisposition of the body to certain functional abilities and reveal a tendency to certain diseases. However, the construction of the curve on the basis of average age indicators still averages of their manifestation and led to the high forecast error [17].

In accordance with measurable indicators, such anthropometric indices are considered: overall weight and height (body length and weight used in their construction), thoraco-growth (measured perimeter of the chest and body length), complex (use at least three anthropometric indices) and others (not covered by the type) [14].

The main interest for the characteristics of body composition are those indexes, which participate in the construction of body mass sign i.e. body mass index. Previously popular indexes of Brock, Pine, Quetelet, Levee, Rohrer have been used [18].

In practical medicine, the body mass index (BMI) is used for diagnostics of obesity. It is calculated according to the following formula:

$$
\text { BMI }\left(\mathrm{kg} / \mathrm{m}^{2}\right)=\text { body mass }(\mathrm{kg}) / \text { height }\left(\mathrm{m}^{2}\right) \text {. }
$$

Despite significant drawbacks, BMI remains the only internationally recognized criterion for assessing overweight [19].

At the same time an increase in BMI, or finding it in the normal range not always allow to judge the presence or absence of obesity. Also, when underdeveloped muscle tissue at excess of adipose tissue increase of BMI may not appear. This will contribute to bad accuracy of the index [20].

A more attractive approach is that of Foster, Greer and Thorbecke. In general terms the index can be written as:

$$
\left.\mathrm{BMI}_{\alpha}=\frac{1}{\mathrm{n}_{\mathrm{BMI}_{\mathrm{i}}>\mathrm{BMI}^{*}}} \sum_{\mathrm{BMI}^{*}}\right)^{\alpha} .
$$

The overall value of the index is a weighted sum of the values of the index for a set of mutually exclusive and exhaustive subsets where the weights are the corresponding proportions of the population. Thus, it is possible to measure the contribution of a particular subgroup to overall obesity [21].

In total, several tens of indexes have been proposed. However, a significant drawback of the existing indexes is the difficulty of an individual evaluation of the physical development of individuals and significant dependence of the index on age.

The authors of [22] revealed the impact of age-related features on its degree severity of the anatomical components of the somatotype. However, this study was aimed only at children of the I and II period of childhood in normal and scoliosis.

The study of the nature of distribution of the body fat mass in persons of all ages, male and female is also known. As a result, the relationship of fat mass and body type taking into account the age and growth characteristics of subjects was found.

A significant drawback of this method is the absence of the submission of the forms of the human body. Modeling forms is mainly due to the development and topography of fat mass and individual genetic characteristics of muscle mass manifestation. Practical research require the creation of such a technique, which would allow by external forms of the body to determine its functionality [23].
The modification of BMI presented in the work [24] enables to present the model of somatotype formation in a specific semantic attribute space with a single measure of height and weight, introduced in the space. A decisive index of physical development is increase of body weight. Distribution of body mass per unit of height is the most simplified representation of body formation. More complete understanding of the body structure, sufficient for reducing a general rule of formation, can be obtained by adding an average body width. An attribute space used in the model, is three-dimensional and based on principal characteristics of the body length, its average width and mass [25].

Effective prevention of obesity can be achieved by understanding the general natural growth and formation of a body as well as causes of observed large variability of existing somatotypes. According to the theory of constitutional predisposition to various diseases, it can be naturally assumed that the metabolism of fats, proteins, carbohydrates, water and salt are closely related to the body's structure, which is an external display of relative proportions of mentioned components of metabolic processes. Their personal expression in the somatotype structure is the most effective indicator of prenosological prediction of constitutional diseases, including obesity.

Understanding the general principles of formation processes in the course of allocation of increasing body mass allows us to identify particular mechanisms that determine the occurrence of individual inclination to certain nosologies. In order to solve this problem, it is necessary to estimate the rate of biological maturation of morphological and functional formations of somatotype and features of the running of biological processes depending on age. Existing empirical materialism and available theoretical explanations of forming the morphogenesis allowed us to build a model describing its running and to identify the most common mechanisms reflecting the whole variety of this phenomenon [26].

From the above, it is necessary to deepen the details of the body forming process, that it is possible, taking into account individual peculiarities of the formation process by using independent volume and structural characteristics of morphogenesis of the body. This can be achieved by constructing the attributive semantic spaces with introduction of a single measure in them.

\section{The purpose and objectives of the study}

The aim is to study the mechanisms of formation and development of overweight and obesity using the semantic space with the orderly height-weight ratio for development of an information diagnostic system for obesity.

To achieve the set goal, the following tasks are to be solved:

1) determine general principles and mechanisms of formation processes of somatotype considering difficulty of morphogenesis for detecting them by development of mathematical and information support of the diagnostic information system of obesity;

2) development of the structure of semantic attribute spaces enabling to model a variability of processes' running and revealing the causes of obesity;

3 ) determine in the developed semantic space conditional norm of variations height-weight ratio. 


\section{Research materials and methods with regard to efficiency of the developed mathematical models application that allow to describe the interdependent relationship of functional systems of the body}

Set of patients has been investigated (155 people), which is divided into five groups: group 1 - patients with normal body weight (29 patients); group 2 - patients who are overweight (37 patients); group 3 - patients with obesity of 1st degree (45 patients); 4th group - patients with obesity of 2nd degree (25 patients); 5th group - patients with obesity grade 3 (19 patients). All patients underwent a comprehensive examination that included measurement of indicators such as weight, height, body type.

We used the theory of similarity and dimension to establish the commensurability of quantitative indicators, expressed in units or percent with respect to the entered standard of comparison. It is possible to establish the permanence of relations considered anthropometric parameters and constancy of occurrence of these relations.

Using the principles of self-organization allows a somewhat different look at the process of formation of obesity.

The central concept in the work is the concept of the semantic space, which means the space-coordinate model of individual or group submissions system. In this space the axis is formed by the data analysis technology and represents a generalized meaning of grounds, which are used for correlating and opposition of objects in its system of relations.

\section{Results of building the structure of semantic attribute spaces for studying the reasons of obesity}

Any chronological age of a given studied population has a typical range of variation of body weight, specific to the age. The distribution of body weight is normal. The modal value, based on the calculated dependence of the weight on the age, reflects the norm, which corresponds to biological age. In this case, the range of variation of biological age corresponds to a given chronological age. The lag of biological age can be observed in case of insufficient weight. The modal value of chronological growth of body weight coincides with the norm of biological age and is the norm of height-weight parameters of a human. Outrunning growth of body weight in comparison with its chronological norm corresponds to obesity. A lag and forestalling of height in comparison with the norm of biological time of growth of body weight are measured in parts of sigma deviation.

The range of variation of the age norm of mass growth corresponds to the norm of formation of the body structure, which in this case is determined by two parameters: the length and the width of a human body. In general case, in order to reach the required accuracy of refinement of features of individual structure of biological development of somatotype and specific violations of its norm, the number of parameters can be increased to any sufficient amount. The range presents constant ratios "body length - body width" for different body weights at specified chronological age. This range reflects variation of age of potential of growth of forming body weight.

Formation of body has varying variation caused by distribution of body weight by its length (short, long) and width (narrow, wide). Direct empirical observations during monitoring of physical development for any chronological age reveal the range of variation of "short and long", "narrow and wide". This allows us to build the required semantic space of ordered representation of somatic type formation for specified chronological age, in which all possible combinations of biological age with individual characteristics of its sorts are presented (Fig. 1).

The drawn grid in the "unit square" represents the measure of sigma deviations from the norm of biological age. The intersection point (9) of coordinate axes and diagonals of the square is the norm of height-weight ratios. Within one sigma deviation, in accordance with the direction of specific individual structures of somatotype composition, eight directions on coordinate axes and diagonals, reflecting a qualitative property of the body structure, are indicated.

Distance in the respective direction reflects the measure of disorder of somatotype structure measuring in parts of sigma deviation from the norm of biological development. The range of one sigma deviation corresponds to the functional optimum of somatic type variation.

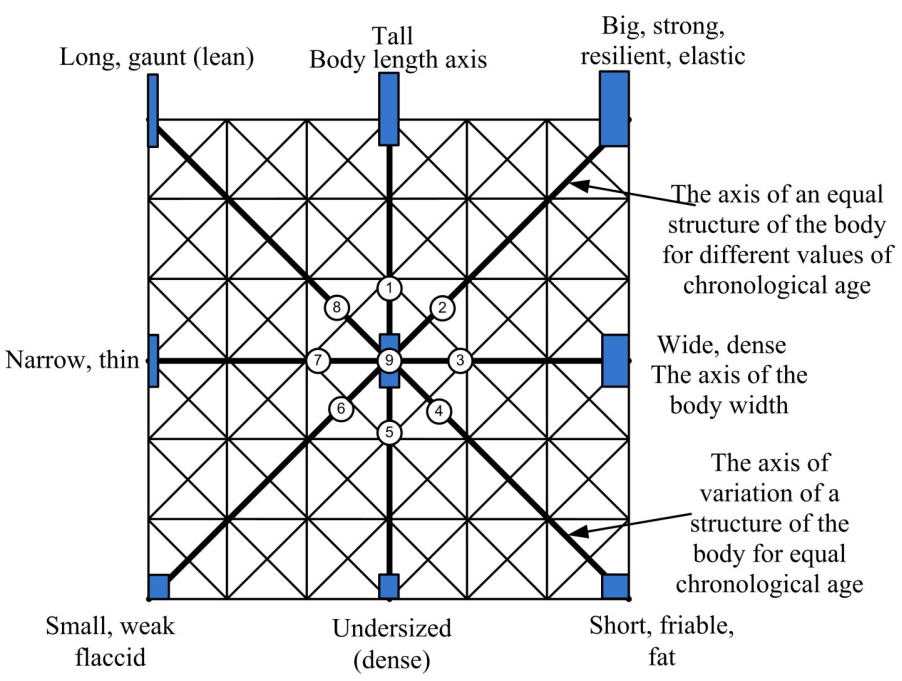

Fig. 1. Semantic attribute space of ordered representation of height-weight ratios

The space shown in (Fig. 1) reflects the variability of biological age for a given chronological age. By adding the time coordinate, similar results will be obtained. According to chronological age, mentioned points can be moved along the axes: "length", "width", and "time". There is a plane in this space passing through the axis of "time" and the axis corresponding to the norm of the ratio "length-width", where the trajectory of growth of body weight corresponding to the norm of biological age and chronological norm of population development is reflected.

Based on empirical data [27] and theoretical concepts of running the process of growth in a limited space, the process's trajectory of moving the norm of biological development in the marked plane is approximated by an exponential curve [28]. The range of variability of formation of the body structure moves relatively to the norm of growth according to features of physical development.

According to distribution of variability of biological age and features of its running, presented in (Fig. 1), the norm of the process has the highest viability in a respective envi- 
ronment of its running. The measure of deviation of body formation determines the value of emerging direction of disorders in synchronization of interdependent relationships of morphological and functional formations and natural decrease of their viability.

The direction of deviation determines the qualitative cause of emerging desynchronization of these relationships and points out to reasons of decreasing viability of interaction of such kind. The general structure of building of

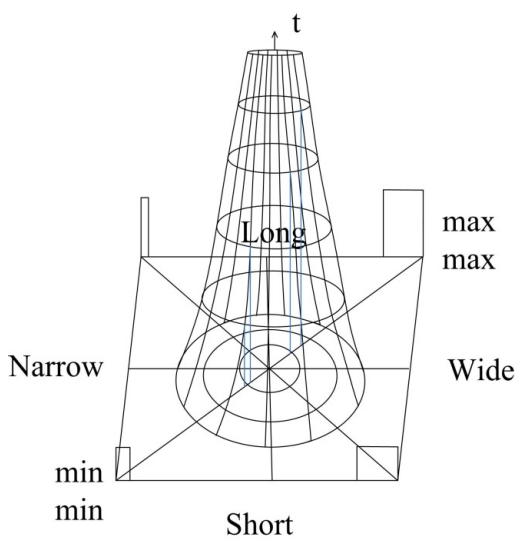

a

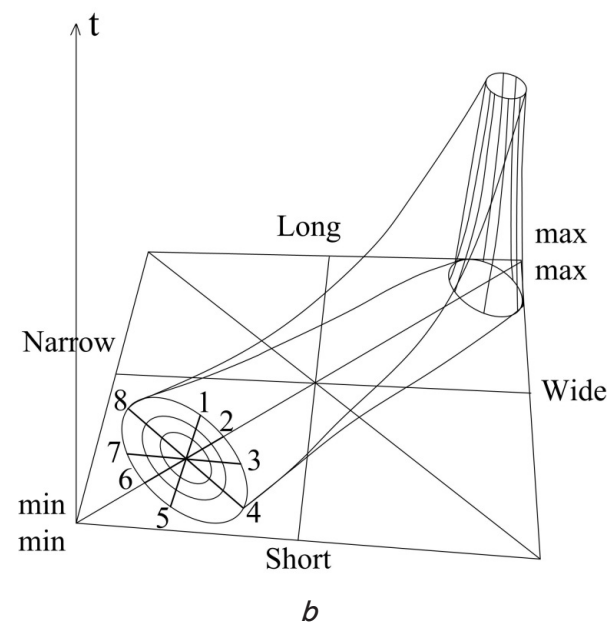

Fig. 2. Change in number of population variability of different forms of morphological and functional formations with deviation from the norm of biological development: $a-$ the morphometric structure of the vertical axis, representing the time attribute, reflects the viability of morphological and functional structures with abnormal biological age of physical development (point 9 in Fig. 1);

$b-$ the generalized structure reflecting the change in population composition of somatotypes subject to their elimination

Conditions of equilibrium state's preservation depend on measure of deviation of somatotype structure and norm of age relations of morphological and functional structures. This condition is the basis for the construction of analytical description of interrelated processes of height-weight variation of the somatotype structure and duration of their synchronization with biological age. These relationships are described by an exponential function.

A logistic curve is the law of growth of parameters' values that determine the development and formation of a body in conditions of limited supplying environment. The surfac- es, forming the generalized structure, have an asymptotic behavior of its parameters with respect to the time of their biological maturity. The characteristic of the somatic type, corresponding to the structure of somatic type for the norm of biological age (point 9 in (Fig. 1)), has unlimited time of viability in the stationary environment.

If synchronization of the relationship "object-environment" is carried out in non-stationary environment, then equilibrium points in the range of "drift" can exist for unlimited period of time. In doing so, the environment must not exceed the range of adaptive functional optimum. Conditions of such relationships are described by the VolterraLotka-Kolmogorov system of equations [28].

The presented schemes show the measure of inconsistency in using height-weight ratios for evaluating the presence of overweight as an index of obesity. Height-weight ratios reflect the value of deviation from the norm of biological development, when in general case the obesity reveals itself as one of the forms of overweight at the equal height. They are inadmissible for constant height-weight index of all persons with different weight while maintaining a normal body structure that corresponds to the lines min; min-max; max in (Fig. 2).

Understanding the nature of development of metabolic syndrome or "X-factor", associated with obesity, requires the modeling of its occurrence. This process is an integral component of overall metabolism, aimed at satisfying the inquiry in interdependent relationships of organism systems. Lipid, salt-water, carbohydrate, and protein metabolism is carried out according to the principle of relations "inquiry-satisfaction" described by the Volterra-Lotka mathematical model. The process of meeting any satisfaction of emerging demands, creating an inquiry, is carried out by two forms of implementation having the dichotomous structure (extensive and intensive form). Extensive process is an extensive process associated with a certain number of continuously functioning structures providing satisfaction of emerging demands. If the inquire mismatches, variation of demand may be adjusted by deposit of produced product. The amount of required depot is formed under the impact of the range of variation of an inquire. The second way of meeting demands is related to intensive form of activity of respective functional structures.

Concerning the meeting emerging inquire, the similar structure, related to consumption and accumulation of necessary capacity, is acting. Hence, an emerging inquiry implies consumption and depletion of deposits, and satisfaction is carried out by completing and accumulation of them (by depositing). The interaction of these processes can be considered in the two-dimensional semantic space in the form of a square, which reflects an ordered presentation of possible variations of interaction modes of relations "inquiry-satisfaction" (Fig. 3).

The diagonals of the unit square represent the twodimensional orthogonal space, which in relation to the space, reflecting the interaction of depletion and accumulation processes, rotated at $45^{\circ}$. It reflects the result of participation in parts in interaction of attributive characteristics of structural organization of the process "satisfactionconsumption". All interacting attributes are measured in parts of sigma deviation from the norm of their relations, which is the point of intersection of diagonals and axes, similar to the point (9) in (Fig. 1).

The inner square corresponds to the area of functional optimum. The area between the middle and inner square cor- 
responds to manifestation of irreversible processes (development of pathology). The area between the middle and outer squares corresponds to prominent pathological processes. The vertices of the square or endpoints of diagonals are results of extreme forms of manifestation of interdependent processes in the attribute space of relations.

$$
\text { (IC) }
$$

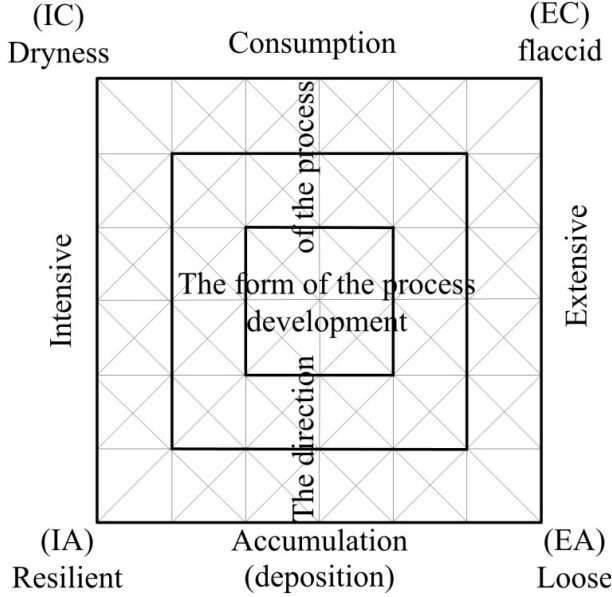

Fig. 3. Semantic attribute space of relations "inquirysatisfaction": IC - intensive, consumption; EC - extensive, consumption; EA - extensive, accumulation; IA - intensive, accumulation

EA in its extreme manifestation generates looseness of structure, the diametrically opposite point IC creates dryness of the structure. In its turn, EC generates sluggishness of the structure and IA leads to formation of elasticity of the structure.

An accumulated potential reserve enables to provide compensation of exhausted system. Stimulation, in turn, provides enhancement of activity of an extensive process of supply. Mutually antithetical direction of the mentioned processes generates a stable form of equilibrium, which is supported in the area of functional optimum of interdependent relationships. If the equilibrium state in any dichotomous direction of these relationships is violated, development of a certain type of pathology starts.

An excessive accumulation of the products of activity of any system, playing the role of a demands satisfier of its product, leads to suppression of its activity that acts as a homeostasis' regulatory mechanism. The external compensation, in the final count, leads to degradation of its own production of the corresponding product. In its turn, the prevalence of stimulation processes over the process of compensation in regulation of interdependent relationships of organism's systems leads to depletion of life-support systems.

Thus, a dichotomous relation of compensation and stimulation processes in ensuring the dynamic equilibrium, in the case of violation of their relative proportion in implementation of joint activities, leads to development of relevant dichotomous pathologies. These deviations are related to suppression of proper function during excessive deposit of its products and exhausting of potential abilities in conditions with enhanced stimulation of their activity.

The two-dimensional semantic space shown in (Fig. 3) can be supplemented by the third independent coordinate, which acts as the axis "compensation-stimulation". This allows us to consider all possible forms of interactions between involved attributes in organization of a joint provision of viable relations. The structure of such a three-dimensional attribute space is represented in (Fig. 4).

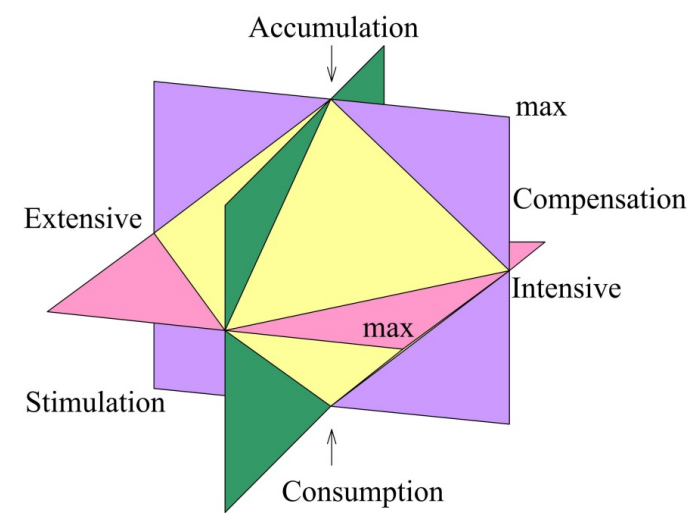

Fig. 4. Semantic attribute space reflecting the mutual support of viable relations

Each of marked coordinate planes is the two-dimensional space of running of dichotomous processes of accumulation and consumption (Fig. 5, a), compensation and stimulation (Fig. 5, $b$ ), extensive and intensive (Fig. 5, c). These processes are described by the Volterra model "inquiry-satisfaction".

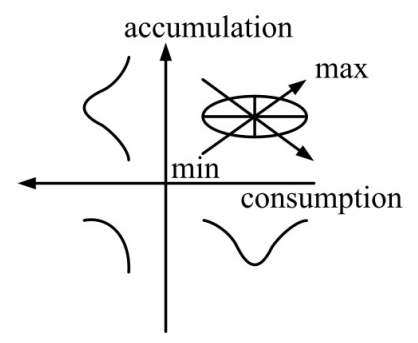

$a$

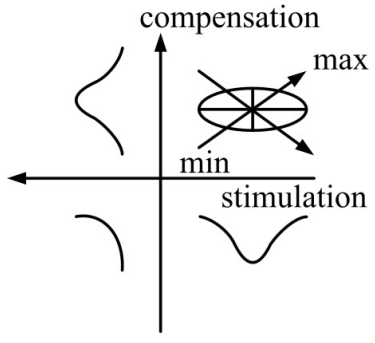

$b$

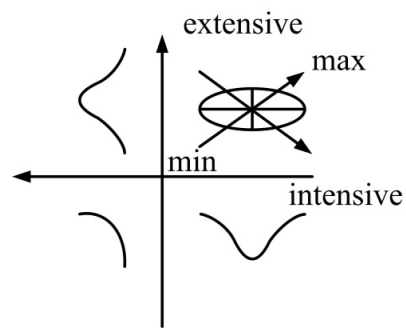

c

Fig. 5. Dynamics of development of interdependent relationships between three dichotomous pairs of attribute characteristics ensuring viability of morphological and functional systems of an organism: $a$ - dichotomous pairs accumulation and consumption; $b$ - dichotomous pairs compensation and stimulation; $c$ - dichotomous pairs extensive and intensive

The analysis of the vibrational process of the Volterratyped system in the represented two-dimensional spaces allows us to determine the area of stable relationships and calculate their boundaries on the approximating hyperbolic curve. This curve reflects the manifestation of the WeberFechner law, however, the limits of applicability of the curve remain uncertain. 
In the representation of this relation, the boundaries of the hyperbole, within which the law of "strength-duration" is applicable, are defined. If we move the equilibrium point of the stable cycle through the line of potential tension (min-max) of dichotomous relations, we will observe the analytical dependence reflecting an asymptotic behavior of the control process of equilibrium ratio, that requires to add a time axis to the phase space in Fig. 5. A deeper description of these interdependent processes can be achieved by using an octahedron, as a space for displaying interacting attributes instead of the cube. Despite the fact that the construction uses the same coordinate axes and obtained diagonals of coordinate planes, octahedra carry a completely different information about represented interdependent relationships of considered attributes in their semantic space. This is primarily related to different numbers of the cube's and octahedron's faces. Besides, two octahedra rotated to each other by $45^{\circ}$ can be inscribed in a cube. This provides an additional information on existing interdependent relationships of considered relations of the respective semantic space.

Stability of interdependent relationships, preserving the vitality of the whole organism, is achieved by synchronizing their joint activities. Deviation of any of these relationships beyond the boundaries of the functional optimum results in de-synchronization of such relations. In the real world, this causes the asymmetry of blood circulation and violation of homeostasis. This process is local and determined by a competitive distribution of limited capacity of the internal environment. These trophic processes in the simplified form of their relationships can be represented as two competing localized centers.

Such models give a possibility to drill deeper in the nature of occurrence of these processes as well as to tackle a number of tasks not available in direct experimental studies.

Return of the system to a stable state is related to directional movement of the considered attributes in the space of system-forming relations to the norm of their initial state. The model of such running of a process is based on the use of directed control of slowly changing parameters in the dichotomous relations: accumulation and consumption, compensation and stimulation, extensive and intensive accumulation shown in (Fig. 5). Such a model behavior reveals the sense of reversibility of processes and can be applied for studying directional stabilization of metabolic processes associated with lipid, protein, carbohydrate and water-salt metabolism. Stabilizing effect uses the impact by compensation and stimulation, implemented through the influence of environmental factors.

The reversibility of processes is naturally implemented in the area of a functional optimum with respect to the normal state. Depending on the distribution of available potential of the supply (produced or compensated) and competitive relations to emerging meeting demands, the current state of redistribution of the internal environment is determined. This process can be presented in the three-dimensional space with the following, axes: the value of an inquiry, the space of its distribution, and duration of its running. This semantic attribute space can be presented as follows (Fig. 6).

The cube vertices define a direction of observational pathology of accumulation of metabolic products. The degree of its manifestation is determined by distance in parts of sigma around the equilibrium point in the corresponding direction of the diagonals of the cube.

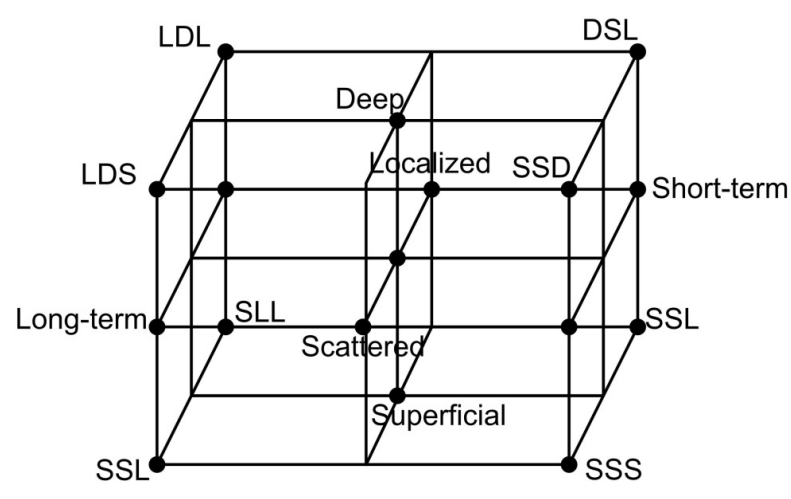

Fig. 6. The semantic attribute space of representation of features of redistribution of metabolic processes' products in providing interdependent relationships: LDL - long-term,

deep, localized; DSL - deep, short-term, localized;

LDS - long-term, deep, scattered; SSD - scattered,

short-term, deep; SLL - superficial, long-term, localized; SSL - short-term, superficial, localized; SSS - short-term, superficial, scattered; SSL - scattered, superficial, long-term

As for the previous cases, three-dimensional spaces in the form of cube and octahedron can be constructed on the base of independent coordinates. Simulation of the process of distribution of the product of inquire allows us to present metabolic processes' derangements resulting from excessive or inadequate intake of vitally important components. Variability of derangements will be determined in the form of: "local or scattered" disturbance seats, "superficial or deep" existing derangements, "short or longtime" derangements. Construction of models and revealing observable disorders with their help enables to systematize the symptoms of various diseases and mechanisms of their occurrence.

\section{Discussion of the research results of formation and development of overweight and obesity}

The attribute space presented in the work is threedimensional and based on principal characteristics of body length, its average width and mass.

Comparability of quantitative indices is achieved by introducing dimensionless units of their representation, expressed in parts or percentage with respect to the introduced standard of comparison. This enables to prove the constancy of ratios of considered parameters as well as the constancy of occurrence of these relations. In order to exclude absolute values of measured parameters and highlight solely qualitative structure of an inspected subject, it is necessary to compare body's length with its measured parts.

The obtained result opens up opportunities for development of preclinical diagnosis and development of methods of easy-to-use preventive measures of embedded constitutional violations.

Also, the research results can be used to trace individual dynamics development of body changes regarding statistical norm.

In the future, it is supposed on the basis of studies to develop methods for the automated construction of attributive semantic spaces. This will allow to study the formation of obesity by modeling the reversibility of the process, depending on the measure of the severity of its violations. 
Using the obtained results in development of the diagnosis information system of obesity will improve the quality and efficiency of diagnosis. This will give the opportunity to explore the formation of obesity by modeling the reversibility of processes, depending on the severity of their violations.

In the future, it is necessary to analyze in detail the representatives of different age and sex, the territorial and constitutional groups for proper evaluation of the process of formation for the various samples.

\section{Conclusions}

1. The volume as some form of limiting space formative biomass has mechanisms that can ensure its increase or decrease. The discrepancy between the quantitative characteristics of the changes in the volume and growth in them weight lays the subsequent shaping process variability diversity. A measure of deviation from the normal structure of the somatotype of biological development measured in fractions sigma deviation that is characteristic of formation in obesity and helps to explain the mechanisms of its development. General principles and mechanisms of the processes of formation of somatotypes determine the occurrence of individual inclinations forming process considering constitutional features of a person, and reflect the diversity of morphogenesis process. This is possible with development of the appropriate mathematical apparatus. Automation of the results using the diagnostic information system of obesity improves the quality of diagnosis of this disease.

2 . The attribute space presented in the work is threedimensional and based on principal characteristics of the body length, its average width and mass. Comparability of quantitative indices is achieved by introducing dimensionless units of their representation, expressed in parts or percentage with respect to the introduced standard of comparison. That enables to prove the constancy of ratios of considered parameters as well as the constancy of occurrence of these relations. In order to exclude absolute values of measured parameters and highlight solely qualitative structure of an inspected subject, it is necessary to compare body's length with its measured parts.

3. Distance from point 9 in the respective direction reflects the measure of disorder of somatotype structure measuring in parts of sigma deviation from the norm of biological development. The range of one sigma deviation corresponds to the functional optimum of somatic type variation.

The development of the diagnostic information system of obesity based on the results obtained will improve the quality of diagnosing people with this pathology. Automation of the data processing of patients with obesity allows to speed up the diagnosis of the disease, to explore more patients, improve the quality of research, control the therapeutic process, as well as reduce the number of errors associated with the routine work of medical staff. Improved diagnostics helps to release predictors of obesity, which will improve the early diagnosis of this pathology.

References

1. Nikitin, Yu. P. Rasprostranenie komponentov metabolicheskogo sindroma X v neorganizovannoy gorodskoy populyatsii (epidemiologicheskoe issledovanie) [Text] / Yu. P. Nikitin, G. R. Kazeka, G. I. Simonova // Kardiologiya. - 2001. - Issue 9. - P. 37-40.

2. Vyisotskaya, E. V. Mathematical model's synthesis for information system of adiposity diagnosis obesity in [Text] / E. V. Vyisotskaya, A. P. Porvan, D. A. Ambrosov, A. S. Dobrorodnyaya, I. S. Dobrorodnyaya // Eastern-European Journal of Enterprise Technologies. - 2012. - Vol. 4, Issue 2 (58). - P. 8-12. - Available at: http://journals.uran.ua/eejet/article/view/4208/3971

3. Kalkulyatoryi [Electronic resource]. - Available at: http://beregifiguru.ru/Главная/Калькуляторы

4. Universalnyiy Meditsinskiy Kalkulyator (ver. 4.1) [Electronic resource]. - Available at: http://cardioplaneta.ru/program/68-universalnyy-medicinskiy-kalkulyator-versiya-30.html

5. Diet Assistant - Weight Loss [Electronic resource]. - Available at: http://www.facebook.com/DietAssistant

6. Diagnos.ru [Electronic resource]. - Available at: http://www.diagnos.ru/ddss/

7. Online-diagnos [Electronic resource]. - Available at: http://online-diagnos.ru/diagnostics

8. EMCIMED [Electronic resource]. - Available at: http://www.mcmed.ua/ru

9. Zagrevskiy, V. I. Kompyuternaya tehnologiya otsenki pogreshnosti v opredelenii mass-inertsionnyih harakteristik segmentov tela cheloveka [Text] / V. I. Zagrevskiy, O. I. Zagrevskiy // Visnyk Chernigivs'kogo nacional'nogo pedagogichnogo universytetu. 2014. - Issue 118 (2). - P. 39-44.

10. Uvarova, Yu. A. Programmnyiy kompleks matematicheskogo modelirovaniya sistemyi fizicheskoy nagruzki [Text] / Yu. A. Uvarova, P. E. Uvarov // Vestnik SGUTiKD. - 2012. - Issue 2 (20). - P. 166-169.

11. Antomonov, M. Yu. Konstruirovanie integralnyih pokazateley kolichestvennyih priznakov s pomoschyu odnomernyih i mnogomernyih metodov statistiki [Text] / M. Yu. Antomonov, E. V. Voloschuk // Kibernetika i vyichislitelnaya tehnika. - 2012. Issue 167. - P. 61-68.

12. Filatova, O. V. Raspredelenie somatotipov i tempov polovogo razvitiya u yunoshey v usloviyah gorodskoy i selskoy mestnosti altayskogo kraya [Text] / O. V. Filatova // Ekologiya cheloveka. - 2014. - Issue 2. - P. 12-19.

13. Baskevich, O. V. Interconnection of students' somatic type with somatic health [Text] / O. V. Baskevich // Physical Education of Students. - 2015. - Vol. 19, Issue 6. - P. 4-9. doi: 10.15561/20755279.2015.0601

14. Martirosov, E. G. Tehnologii i metodyi opredeleniya sostava tela cheloveka [Text] / E. G. Martirosov, D. V. Nikolaev, S. G. Rudnev. - Moscow: Nauka, 2006. - 248 p. 
15. Buren, N. V. Klinicheskaya antropometriya kak metod donozologicheskoy diagnostiki konstitutsionnyih zabolevaniy [Text] / N. V. Buren, N. V. Goncharuk, E. A. Zadorozhnaya, A. V. Tamozhanskaya // Slobozhanskiy naukovo-sportivniy visnik. - 2013. Issue 3. - P. 75-81.

16. Breytman, M. Ya. Differentsiatsiya diagnostika endokrinnyih sistem [Text] / M. Ya. Breytman. - Moscow: Medgiz, 1946. - 564 p.

17. Sak, N. N. K morfologicheskim vozmozhnostyam prognosticheskoy otsenki perspektivnosti sportsmena [Text] / N. N. Sak, G. P. Artemeva // Slobozhans'kyj naukovo-sportyvnyj visnyk. - 2005. - Issue 8. - P. 243-247. - Available at: http://www.nbuv.gov. ua/old_jrn/soc_gum/Snsv/2005-08/05snnops.pdf

18. Rusakova, D. S. Sovremennyie metodyi otsenki sostava tela [Text] / D. S. Rusakova, M. Yu. Scherbakova, K. M. Gapparova, Z. M. Zaynudinov, S. I. Tkachev, V. G. Saharovskaya // Eksperimentalnaya i klinicheskaya gastroenterologiya. - 2012. - Issue 8. P. 71-81.

19. Sangwan, D. A study of body mass index between private and government school children [Text] / D. Sangwan // International Journal of Physical Education, Sports and Health. - 2016. - Vol. 3, Issue 1. - P. $63-65$.

20. Anischenko, A. P. Sopostavimost anropometricheskih izmereniy i rezultatov bioimpedansnogo analiza [Text] / A. P. Anischenko, A. N. Arhangelskaya, E. V. Rogoznaya, N. G. Ignatov, K. G. Gurevich // Vesnik novyih meditsinskih tehnologiy. - 2016. - Vol. 23, Issue 1. - P. 138-141.

21. Madden, D. Body Mass Index and the Measurement of Obesity [Text] / D. Madden // Health econometric and data group. 2006. - P. 2-16.

22. Chaplyigina, E. V. Vozrastnyie osobennosti stepeni vyirazhennosti anatomicheskih komponentov somatotipa v norme i pri skolioze [Text] / E. V. Chaplyigina, T. M. Sikorenko, O. A. Aksenova, O. T. Vartanova, K. A. Nor-Arevyan // Fundamentalnyie issledovaniya. - 2013. - Issue 7. - P. 663-665.

23. Dorohov, R. N. Harakter raspredeleniya zhirovoy massyi tela lits razlichnogo vozrasta muzhskogo i zhenskogo pola [Text] / R. N. Dorohov, V. N. Chernova, O. M. Bubnenkova // Uchenyie zapiski universiteta imeni P. F. Lesgafta. - 2015. - Issue 9 (127). P. 91-96.

24. Azhippo, A. Yu. Problema opredeleniya biologicheskogo vozrasta v sisteme otsenki fizicheskogo razvitiya v donozologicheskoy diagnostiki konstitutsionalnyih zabolevaniy [Text] / A. Yu. Azhippo, Ya. I. Pugach, Ya. V. Zhernovnikova // Slobozhanskiy naukovo-sportivniy visnik. - 2015. - Issue 3. - P. 7-12.

25. Pugach, Ya. I. Osnovnyie polozheniya postroeniya semanticheskih prostranstv dlya uporyadochennogo predstavleniya rezultatov issledovaniy [Text] / Ya. I. Pugach // Materialyi za IX Mezhdunarodnuyu nauchno-prakticheskuyu konferentsiyu «B'descheto vprosyi ot sveta ta naukata - 2013». - Sofiya: Bjal Grad - BG, 2013. - P. 5-14.

26. Balsevich, V. K. Ocherki po vozrastnoy kineziologii cheloveka [Text] / V. K. Balsevich. - Moscow: Sovetskij sport, 2009. - 220 p.

27. Volkenshteyn, M. V. Obschaya biofizika [Text] / M. V. Volkenshteyn. - Moscow: Nauka, 1978. - P. 408-418.

28. Samsonkin, V. N. Modelirovanie v samoorganizuyuschihsya sistemah [Text] / V. N. Samsonkin, V. A. Druz, E. S. Fedorovich. Donetsk: Izd. Zaslavskij A. Ju., 2010. - 104 p. 